\title{
ОСОБЛИВОСТІ ОРГАНІЗАЦІЇ ПРОЦЕСУ ФІЗИЧНОГО ВИХОВАННЯ СТУДЕНТСЬКОЇ МОЛОДІ
}

\section{PECULIARITIES OF THE ORGANIZATION OF STUDENTS' YOUTH PHYSICAL EDUCATION}

у статті розглядаються проблеми організаціі срізкультурно-оздоровчого процесу в умовах вищого освітнього закладу, створення належних умов для охорони та зміцнення здоров'я студентської молоді, визначено способи покращення здоров'язбережувального навчально-виховного середовища, а також проаналізовано чинники, які мають негативний вплив на здоров'я молодої людини відповідно до умов розумової діяльності під час навчальновиховного процесу у закладі вищої освіти.

Сучасна студентська молодь мусить бути не тільки всебічно розвиненою та духовно красивою, але і здоровою, фрізично міцною. Сuтуація ускладнилася з переходом на кредитно-модульну форму навчання, що припускає зменшення кількості годин, відведених на фрізичне виховання, і переміщення їх у розряд самостійної роботи, що у разі несформованої мотивації до занять може проявитися в зниженні рухової активності студентів загалом.

Нині запроваджуються профрілактично-реабілітаційні комплекси, прогресивні релакстехнології, де враховані, гармонійно поєднані (упорядковані, адаптовані, індивідуалізовані, дифреренційовані й модернізовані) всі складники формування здорового способу життя: фьзичні вправи, оздоровчий біг, психогігіє нічне та раціональне харчування, дихальна гімнастика, йога-терапія тощо.

Виконання головного завдання фрізичного виховання - зміцнення та збереження здоров'я студентів - здійснюється шляхом систематичного залучення студентства до рухової діяльності, проведення фрізичних тренувань з метою збільшення фуннкціональних можливостей організму, заповнення вільного часу студентів орізичними вправами, має стати сьогодні надважливою стратегією освітнього закладу (з огляду на систему безперервної освіти).

Значним потенціалом у формуванні здоров'я студентської молоді має стати застосування комплексу цікавих сучасних технологій, форм, заходів із фрізичного виховання молоді, з активізації їхньої рухової активності та системи спортивних виховних заходів щодо пропаганди здорового способу життя та мотивації фрізичного вдосконалення.

Ключові слова: здоров'язбережувальні тех нології, розумова діяльність, рухова активність, студент, фрізичне виховання, фрізкультурно-оздоровчий прочес.
The article deals with problems of organization of the physical education and wellness processes in conditions of a higher education and creation of proper conditions for the protection and students' youth health promotion, the ways to improve the health-saving educational environment were identified, also the factors that have a negative impact on health of a young person were analyzed, in accordance with the conditions of mental activity during the educational process in higher education institution.

Modern student youth should be not only comprehensively developed and spiritually beautiful, but also healthy and physically strong. The situation is complicated by the transition of education form to a European Credit Transfer and Accumulation System, which implies a decrease in the number of hours allotted for physical education and their transfer to the category of independent work, which in the case of unformed motivation for the classes may be manifested in a decrease in the students' motor activity in general.

Today the prophylactic and rehabilitation complexes, progressive relaxation technologies are introduced, which include all the components of forming a healthy lifestyle which are harmoniously combined (ranged, adapted, individualized, differentiated and modernized): physical exercises, wellness running, psychic-hygienic and rational nutrition, breathing exercises, yoga therapy and more.

The main task of physical education is a strengthening and preserving the health of students. It is carried out by systematically involving students in physical activity, conducting physical trainings in order to increase the body's functional capacity, filling students'leisure with physical exercises. That should become an important strategy of the educational institution today (including the continuing education)

The use of a complex of interesting modern technologies, forms, activities on a young people's physical education that activate their physical activity, and the system of sports educational measures for the promotion of healthy lifestyles and motivation for physical improvement, should be a considerable potential in shaping the health of student youth.

Key words: health-saving technologies, mental activity, physical activity, student, physical education, physical wellness process.
Постановка проблеми у загальному вигляді. Сьогодення вимагає від сучасних редоомм в освіті вирішення питання виховання здорової, освіченої, активної особистості, де гармонійно поєднані духовне багатство, моральна чистота та фрізична досконалість сучасної молодої людини. Підготовка молоді до життя, праці, творчості закладається саме в студентські роки.
Сучасна студентська молодь мусить бути не тільки всебічно розвиненою та духовно красивою, але і здоровою, фрізично міцною. Звідси спорт має стати масовим громадським рухом, ссрерою загартовування вольових якостей сучасної молодої людини, трампліном для просресійного становлення майбутнього висококваліфікованого і конкурентоспроможного фрахівця. Але ситуація ускладнилася 
3 переходом на кредитно-модульну фрорму навчання, що припускає зменшення кількості годин, відведених на орізичне виховання, і переміщення їх у розряд самостійної роботи, що у разі несорормованої мотивації до занять може проявитися в зниженні рухової активності студентів загалом.

Чи можна знайти альтернативу втраченим навчальним годинам, щоб компенсувати час на збереження здоров'я молодої людини, врахову ючи, що для поліпшення фрізичного стану студентів необхідно підвищити їхню рухову активність. Задача освітньої галузі нині - сфрормувати у молодого покоління чітке розуміння того, що фрізична культура і спорт - це ефективні засоби зміцнення здоров'я, підвищення працездатності та успішності особистості у сучасному суспільстві.

У рамках цієї статті спробуємо віднайти варіант зацікавленості студента у самостійних заняттях фрізичними вправами, здоров'язберігаючими вправами.

Аналіз останніх досліджень і публікацій. Останні дослідження фрахівців розглядають фрізичне виховання як потужний засіб зміцнення здоров'я населення, забезпечення високої працездатності та якості життя загалом. Проблема збереження та зміцнення здоров'я молодого покоління досліджувалася науковцями (В. Білогур, В. Бобрицька, М. Булатова, В. Данилюк, О. Дрозд, Г. Іванова, Т. Круцевич, О. Малімон, І. Назарова, О. Нєчаєва, С. Савчук, Ю. Усачов, Ю. Фатюшин та ін.), які у своїх працях наголошують на значущості стану здоров'я та його безпосереднього зв'язку із професійним становленням молодої людини, фрормуванням іiі особистості.

За даними Л. Крилової, Р. Мотилянської, І. Муравова, В. Мурзи, домінантними аспектами $€$ правильна організація фрізичного виховання у навчально-виховному процесі, нормування рухової активності студентів, педагогічні впливи та керівництво процесом фрормування здорового способу життя в освітньому закладі та поза його межами.

Аналіз психолого-педагогічної літератури дає підстави для твердження, що становлення особистості (професійне, особистісне) передбачає використання сукупності прийомів педагогічного впливу на неї, включення її в різноманітні значущі види діяльності (в тому числі фрізкультурно-оздоровчий процес) 3 метою фрормування системи важливих знань, умінь, навичок, якостей, фрорм поведінки, валеологічної свідомості, позитивної мотивації до систематичних занять фрізичною культурою, спортом, профрілактики шкідливих звичок тощо.

3 огляду на це проблема фрормування здоров'я студентської молоді набуває актуальності з позицій реалізації нових підходів до її розв'язання.

Виділення не вирішених раніше частин загальної проблеми. Дослідження фрахівців свідчать про те, що в сучасній теорії та методиці фрізичного виховання не досить розроблені, обґрунтовані, впроваджені сучасні високоефективні трендові спортивні та фрізкультурно-оздоровчі технології (фрітнес, аеробіка, йога, пілатес тощо), які б сприяли формуванню інтересу до фрізичних вправ та могли би стати нині одним із головних мотиваторів до здоров'язберігаючих занять.

Мета статті - розкрити особливості організації фрізкультурно-збережувального середовища у закладі вищої освіти.

Виклад основного матеріалу. У Національній доктрині розвитку освіти України зазначено: «Здоров'я нації через освіту. Пріоритетним завданням системи освіти $€$ навчання людини відповідального ставлення до власного здоров'я і здоров'я оточуючих як до найвищих суспільних і індивідуальних цінностей» [4].

Важливе місце у формуванні відповідального ставлення до власного здоров'я як запоруки успішності у майбутньому житті (особистому, професійному) відіграють заходи (форми, методи, прийоми) 3 фрізичного виховання, здоров'язбережувальні технології, що є складовою частиною навчальновиховного процесу закладів вищої освіти.

Основною метою фрізичного виховання $€$ фрормування фрізичного, психічного, духовного та соціального здоров'я. У рамках цієї статті зупиняємося на срізичному здоров'ї молоді. Підґрунтям для фрормування відповідального ставлення до власного здоров'я та фрізичного стану особистості є:

- по-перше, підвищення фрізкультурної грамотності у студентства (формування та розширення знань про організм та фрізичний стан, стан фрізичної підготовленості, статури, про засоби впливу на них, методику використання цих засобів тощо);

- по-друге, надважливим $€$ інфрормаційність, пропаганда та роз'яснювальна робота серед молоді стосовно фрізичної культури та здорового способу життя;

- по-третє, безпосередньо практичне впровадження в життя молодої людини моди на спорт, здоров'язабезпечувальну дозвіллєву діяльність, фрізкультурну та рухову активність.

Рухова активність (гіподинамія) студента має велике значення для вдосконалення фрізичного розвитку й підготовленості особистості. Брак рухової активності має негативні наслідки для організму молодої людини i, як наслідок, виникнення серцево-судинних захворювань, діабету, остеопорозу, депресії, окремих онкологічних захворювань.

Справді, найбільш негативним чинником для здоров'я розумової діяльності є зниження рухової активності у поєднанні 3 вимогами до засвоєння великих обсягів інформації, тривалого підтримання уваги, високої психічної стійкості тощо. Унаслідок такого поєднання настає розумове стомлення, що викликає перезбудження і невротизацію. Дослідження В. Бобрицької доводять, що хронічний 
характер розумової стомленості призводить до перевтомлення зі стійким зниженням показника адаптації організму людини до інтелектуальної праці; це і рівень працездатності, і розвиток соматичних хвороб, таких як: погіршення функціонального стану серцево-судинних систем; застійні явища у нижніх відділах легень, черевної порожнини і нижніх кінцівок; зміни загального обміну речовин і розвитку первинного ожиріння тощо [2].

Розумова діяльність супроводжується напруженістю м'язів обличчя, шиї, плечового поясу, що пов'язане з одноманітністю поз під час письма, читання, слухання. Проте активність саме органів «комірцевої» зони тісно пов'язана 3 нервовими центрами, що керують процесами уваги, емоціями, мовою. Уникнути застійних явищ у цій зоні можна лише за допомогою активних рухів із залученням інших м'язових груп (спини, ніг та ін.), що розвантажують м'язи шиї, плечового поясу, обличчя від надмірної напруженості. Характерним для студентства $€$ негативні зміни фрункцій зорового (погіршується гострота зору, стійкість ясного бачення, контрастна чутливість, зорова працездатність) і слухового аналізаторів (понижується рівень слухової чутливості). Науковцями доведені часті випадки невротичних станів, які створюють підґрунтя для розвитку атеросклерозу, злоякісних новоутворювань, цукрового діабету тощо.

Якщо зробити стислий аналіз обставин, що викликають зміни у способі життя студентів (необхідність засвоєння, глибокого розуміння, осмислення і відтворення великого обсягу навчального матеріалу, засвоєння нової соціальної ролі «студент», зміна соціального оточення, зміна способів комунікації тощо), можна побачити цілу низку внутрішніх суперечностей психічного стану, негативні переживання емоційного характеру, перебудови звичного стилю поведінки молодої людини і бажанням попри все здобути високий рівень свого IQ або здатися перед великим навантаженням навчального процесу і не робити кроки «напруження» до саморегуляції, самовиховання та ін. Узагальнюючи, виокремимо чинники, які у процесі навчальновиховної діяльності студентів можуть мати негативний вплив на їхнє здоров'я, а саме:

- посилені вимоги до засвоєння значного обсягу навчального матеріалу;

- тривале навантаження на деякі фрункціональні системи організму, зокрема опорно-руховий апарат, аналізаторні системи;

- брак навичок раціональної організації навчальної та дозвіллєвої діяльності.

3 огляду на це перед сучасною вищою освітою доцільним є завдання - порушити питання пошуку ефективних здоров'язбережувальних технологій та організації раціонального студентського дозвілля у ракурсі фрізичного виховання, фрізичної культури та спорту. У межах цієї статті зупинимося на проблемі організації якісного фрізичного виховання в умовах закладу вищої освіти, підвищення фрізичної активності студентської молоді.

Фізичне виховання студентів органічно пов'язане 3 навчальною, позааудиторною, культурно-масовою та іншими видами діяльності. Фізична активність включає ранкову гімнастику, прогулянки на свіжому повітрі, оздоровчий біг, плавання, ходьбу на лижах, домашню фрізичну працю, аеробіку та її різновиди, навчальні заняття фрізичною культурою, спорт (різні види).

Виходячи із задач та умов освітнього закладу, у процесі фрізичного виховання використовуються такі форми роботи:

1. Обов'язкові навчальні дисципліни та фракультативні заняття з різних видів спорту.

2. Фізкультурно-масові заходи.

3. Спортивно-оздоровчі табори.

У багатьох країнах (Японії, США, Канаді та ін.) $€$ спеціальні навчальні курси, дисципліни, мета яких - надати молоді уявлення про фрізичну культуру, навчити основ фрізичної освіти (знання про вплив фрізичних вправ на стан здоров'я, працездатність; про гігієнічні правила під час виконання орізичних вправ; про загартовування водою та повітрям; про режим дня та руховий режим; знання, необхідні для виконання фрізкультурно-спортивної діяльності тощо). Цікавою є програма Слов'янського педагогічного університету «Теоретичні і методичні основи фрізичного виховання та реабілітації». Головний акцент програми занять - від навчання рухових умінь і навичок до вдосконалення їх індивідуального фрізичного розвитку, фрормування фрізичної культури, культури здоров'я, стійкої соціально-психологічної установки на активні заняття фрізичними вправами. Заняття підвищують у студентів інтерес до таких занять. Значна увага приділяється розробці особистісної методики таких занять, індивідуалізації культурно-оздоровчої роботи, активному включенню таких занять упродовж усього життя.

Зазвичай навчальна діяльність обмежується аудиторними заняттями, доповнюється практичними та індивідуальною і самостійною роботою, консультаціями, заліками тощо. Спостереження, бесіди та інтерв'ювання студентів дало змогу увійти у новий вимір студентського буття, сприяло організації цілеспрямованого дозвілля, корисного для власного здоров'я молодої людини. Тому вумовах закладу вищої освітипорядзобов'язковими заняттями (гімнастика, лижна підготовка, плавання та ін.) працюють фракультативні заняття-практикуми з фрізкультурно-масової роботи з молоддю. На цих заняттях здійснюється підготовка студентів до туристичних мандрівок, фрлешмобів з прищеплення студентам умінь та навичок з фрізичної культури, а для студентів педагогічних вузів це ще й навчання організації та проведення змагань, рухливих ігор та інших видів фрізкультурно-оздоровчої роботи 
3 дітьми. В організації цієї діяльності широко використовується самостійна підготовка студентів до проведення змагань, походів, фрлешмобів тощо.

Безумовно, в умовах освітнього закладу мають працювати спортивно-оздоровчі секції 3 ритмічної гімнастики, фрітнесу, загальної фрізичної підготовки, проводитися змагання, спортивно-оздоровчі заходи, тематичні свята. Широкий діапазон фоорм заходів 3 фрізичного виховання (День фрізкультурника, День здоров'я, День туриста, «Козацькі розваги», «Веселі старти», Спартакіади, естафети, марафони тощо) стимулює зацікавленість студентської молоді, забезпечує молодій людині можливість спробувати власні сили та мотивує до фрізичної активності.

Організація оздоровлення та відпочинку студентства під час навчально-виховного процесу у закладі вищої освіти в умовах проживання у студентському гуртожитку, в оздоровчих спортивних таборах, у разі організації раціонального студентського дозвілля є багатогранним комплексом зміцнення здоров'я, профрілактики захворювань, фрормування здорового способу життя молодої людини.

Слід пам'ятати, що ефективність процесу залучення молоді до здорового способу життя безпосередньо залежить від профресійної майстерності тренера-педагога, яка виражається у підборі та застосуванні цікавих, новітніх методів, прийомів, засобів, фрорм, технологій не тільки в навчальному процесі, а ще й у позааудиторній діяльності студентської молоді та у доцільному, змістовому плануванні й організації дозвіллєвої діяльності студентської молоді.

Так, розробляючи нові фрорми і технології, слід враховувати статеву специфіку організму, вікові, індивідуальні, фрізіологічні особливості, активність (суспільну, соціальну) студента, захоплення сучасної молоді тощо. Наголошуємо, що фрізичне виховання реалізується через взаємозв'язок навчання (передачу освітнього досвіду) й виховання (формування мотивації, власний досвід).

Нині на зміну фоомі лікувальна фрізична культура (оновлення здоров'я студентів, попередження наслідків патологічних процесів, негативних побічних дій) запроваджуються проорілактично-реабілітаційні комплекси, прогресивні релакс-технології, де враховані, гармонійно поєднані (упорядковані, адаптовані, індивідуалізовані, дисеренційовані й модернізовані) всі складники фрормування здорового способу життя: фрізичні вправи, оздоровчий біг, психогігієнічне та раціональне харчування, дихальна гімнастика, йога-терапія тощо.

Арсенал засобів, що забезпечують високий рівень фрізичного стану, різноманітний: ранкова зарядка, спортивні ігри, профілактична ходьба, соціально-спортивні марафони, фрлешмоби, туризм тощо. Однак брак інструкторів-методистів, висококваліфрікованих тренерів, відсутність чіткого регламентування в роботі педагога та адекватної оплати його праці, недостатня матеріально-технічна база спортивних комплексів (спортзали, майданчики, басейни) освітніх закладів та їх стан гальмує процес покращення стану фрізичної культури.

Слід зазначити, що результативність занять та стимул до активної участі у заходах з фрізичного виховання напряму залежить, власне, і від особистості самого тренера, педагога. Підтягнутий, спортивного вигляду педагог користується повагою з боку студентської молоді та швидше завойовує авторитет серед вихованців. Саме він може бути для студентської молоді зразком здорового способу життя (рекомендувати студентству загартовування водою, сонцем і повітрям тощо) та мотиватором для студентів покращити свій фрізичний стан.

Ось лише деякі особливості організації фрізичного виховання під час навчання студентської молоді у закладі вищої освіти, які слід враховувати, на що звертати увагу, які впливатимуть на обрання здорового способу життя сучасної молоді.

Висновки і перспективи в цьому напрямі. Виконання головного завдання фрізичного виховання - зміцнення та збереження здоров'я студентів - здійснюється шляхом систематичного залучення студентства до рухової діяльності, проведення фрізичних тренувань 3 метою збільшення фрункціональних можливостей організму, заповнення вільного часу студентів фрізичними вправами, має стати нині надважливою стратегією освітнього закладу (з огляду на систему безперервної освіти). На нашу думку, значним потенціалом у формуванні здоров'я студентської молоді має стати застосування комплексу цікавих сучасних технологій, фрорм, заходів із фрізичного виховання молоді, з активізації їхньої рухової активності та системи спортивних виховних заходів щодо пропаганди здорового способу життя та мотивації фрізичного вдосконалення. 3 огляду на актуальність проблеми, слід надалі дослідити психолого-педагогічні умови фрормування потреби в здоровому способі життя студентської молоді у процесі фрізичного виховання в умовах освітнього закладу та соціалізації особистості у сучасному суспільстві.

\section{БІБЛІОГРАФІЧНИЙ СПИСОК:}

1. Актуальні проблеми фрізичного виховання різних верств населення : матеріали II Всеукраїнської науково-практичної конференції (Харків, 20 травня 2016 р.) Харків : ХДАФК, 2016. 228 с. URL: http://hdafk. kharkov.ua/ua/materiali-internet-konferentsiji-2016.

2. Бобрицька В.І. Формування здорового способу життя у майбутніх учителів : монографрія. Полтава, 2006. 432 с.

3. Козак Є.П. Формування ціннісного ставлення до фрізичної культури у студентів вищих педагогічних навчальних закладів : монографрія. Кам'янецьПодільський, 2012. 168 с.

4. Національна доктрина розвитку фрізичної культури і спорту. URL: http: //zakon.rada.gov.ua/laws/ show/1148/2004. 